\title{
MODEL OF ACOUSTIC EMISSION SIGNAL AT SELF- ACCELERATED CRACK DEVELOPMENT
}

\section{Babak, S. Filonenko, V. Kalita}

National Aviation University, Kiev, Ukraine.E-mail: fils@ukrpost.net

Received 0411 2004, accepted 29082005

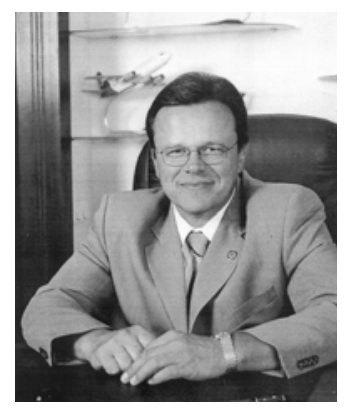

Vitalii BABAK, Prof Dr Habil

Date and place of birth: 1954, Lubny, Ukraine

Education: Kiev Polytechnic Institute

Affiliation and functions: Rector of the National Aviation University since 1998, $1995-\mathrm{PhD}$

from Kiev Polytechnic Institute

Research interests: diagnostics of technological processes, laser and computer modeling and manufacturing, automatic diagnostics systems

Publications: over 300 books and articles

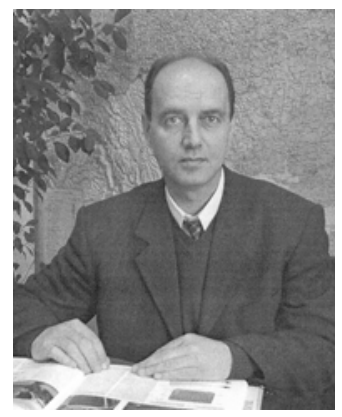

Sergay FILONENKO, Prof Dr Habil

Date and place of birth: 1954, Echmiadzin, Armenia

Education: Kiev Polytechnic Institute

Affiliation and functions: deputy director Institute of information-diagnostic systems at National

Aviation University since 2000, 2003 - PhD from National Aviation University

Research interests: diagnostics of technological processes, automatic diagnostic systems

Publications: over 130 books and articles

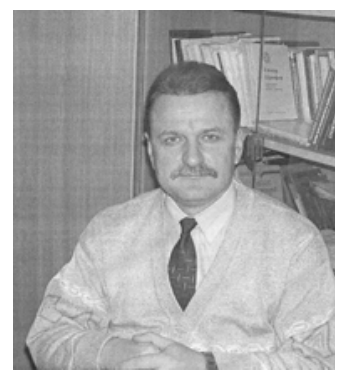

\section{Viktor KALITA}

Date and place of birth: 1962, Chernigov, Ukraine

Education: Rostov on Don State University

Affiliation and functions: ass.prof. of physics, National Aviation University since 2000, 1991 -

Cand.of Sci. (Eng.) from Rostov on Don State University

Research interests: solid-state physics, technical diagnostice

Publications: over 46 articles

Abstract. The article is devoted to the theoretical analysis the problem of acoustic emission signals application for the detection of self-accelerated crack development. The acoustic emission signal model has been proposed which takes into account the change of crack propagation velocity in the process of material loading. The process of self-accelerated crack development results in growth of acoustic emission signal amplitude and compression the signal in time.

Keywords: model, acoustic emission, strength, crack growth, loading, signal of acoustic emission, distribution of strength, fracture, structural heterogeneity.

\section{Introduction}

During the loading of the material, as is well known, gradual development of plastic deformation processes appearance and growth of cracks occur [18, 13]. The results of experimental research $[3,4,5]$ show that these processes are the source of acoustic emission signal radiation $(\mathrm{AE})[15,6,4]$. One of the directions in investigating the $\mathrm{AE}$ phenomenon is studying the form of the
AE signals registered. A considerable number of works have been dedicated to their study $[7,2,1]$. At the same time, published material do not always contain research related to the theoretical description of $\mathrm{AE}$ signals and explaining the difference between the signals registered during plastic deformation and growth of cracks in the material. The models available, for example [16] and 17], show that a primary AE signal represents a video pulse. They however do not take into account the real conditions 
of the behavior developing in the material and do not explain the existence of their complex form. Therefore the real AE signal is shown as follows

$$
U(t)=\sum_{i} A_{i} F_{i}\left(t-t_{i}\right) \text {, }
$$

where $A_{i}$ is a random amplitude of the pulse appearing in a random moment of time $t_{i} ; F_{i}$ - characteristics of a single-pulse form. Summing up is produced along the total of the pulses $n$, registered by an AE sensor.

In other words, an AE signal is presented as a sum of primary signals having random amplitude and time of appearance. It is thus considered that the signal form is initially considered common for all signals [17, 5, $3]$.

At the same time, experimental research shows that $\mathrm{AE}$ signals for the processes of plastic deformation and crack growth differ from each other in form. In works [11] and [12], with certain assumptions taken into account, the models of forming AE signals when a fragile crack is developing in the material and plastic deformation is progressing have been developed. The results of AE signal modeling carried out, in accordance with the models developed, allowed their complex form to be explained It was thus shown that the transformation of $\mathrm{AE}$ signal form is considerably influenced by the speed of processes developing in the material at their loading.

In considering the $\mathrm{AE}$ signal model from a fragile crack developing in some heterogeneous area and in modeling the forming signal, some works state that the destruction of elementary volumes takes place with constant speed or speed of destruction at some instants of time changes, i.e. it can increase or decrease [11,9]. It is in accord with the existing ideas about the development of the destruction process and is related to random distribution of elementary volume characteristics in their strength [22]. At the same time, when a crack is developing, the destruction of every elementary volume results in redistribution of tensions in the heterogeneous area and increase of local tension applied to non-destructed volumes remaining in the heterogeneous area. Such an increase by all means must influence the acceleration of the destruction process, i.e. the destruction process (crack growth) can have a self-accelerated nature of development.

Mathematical description of AE signal from a fragile crack, appearing in a local heterogeneous area, with self-congruent character of its development taken into account, will be performed. Besides, its influence on the parameters and form of an AE signal will be shown.

\section{Model of acoustic emission signal}

Let us assume that in the ideal homogeneous specimen of material there is some local heterogeneous area, which is located in a plane. Its size is much smaller than the model size, i.e. the heterogeneous area $\left(S_{T}\right)$ is considerably smaller than the specimen cross-section $(\mathrm{S})$, $S_{T}<<S$ (Fig.1). We will presume that when the increasing stretch forming tension to the specimen of the material that is applied perpendicularly to the plane of existing heterogeneity, in the area it occupies, a crack appears. As in previous research [16], we will consider that the area of heterogeneity consists of separate minor volumes (Fig.1), their degree $(\ell)$ being considerably smaller than the degree of the smallest internal heterogeneity $(\lambda)$ in the area $S_{T}$, i.e. $\ell<<\lambda$. Crack in plane $S_{T}$ appears by means of mechanical destruction of its small volumes which possesses different levels of strength (we mean local strength of separate volumes). Their destruction takes place when the value of the tension applied achieves the value of the local tension of separate elementary volume destruction.

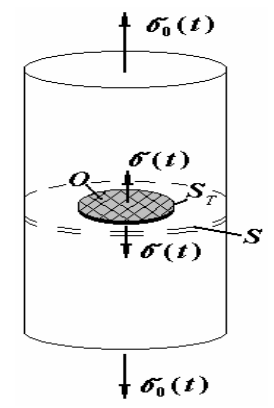

Fig 1. Crack growth in the material model with structural heterogeneity: $\mathrm{S}-$ cross-section area of the specimen; $\mathrm{S}_{T}$ - area of heterogeneity; $O$ - elementary volume in the area of heterogeneity; $\sigma_{0}(t)$ - change of external tension (external lade); $\sigma(t)$ - change of local tension in the area of heterogeneity

In this case, at some tension $\sigma$ applied, the number of local volumes destructed will be determined by the integral

$$
N_{P}=N_{0} \int_{0}^{\sigma} p\left(\sigma_{p}\right) d \sigma
$$

where $N_{0}, N_{P}$, - total number of volumes in the area of heterogeneity and the number of volumes destructed; $p\left(\sigma_{p}\right)$ - function of distributing volumes in the area of heterogeneity relative to strength.

The type of function $p\left(\sigma_{p}\right)$ is determined experimentally when testing the material specimens of identical size on destruction. The distribution $p\left(\sigma_{P}\right)$ looks like [21, 22]

$$
p\left(\sigma_{p}\right)=c \sigma_{p} \exp \left(-b \sigma_{p}\right) \text {, }
$$

where $c, b$ - empiric distribution coefficients.

The increment of the number of destructed volumes for the time $d t$ will be equal to

$$
d N_{P}=N_{0} p[\sigma(t)] d[\sigma(t)],
$$

where $d[\sigma(t)]$ - increment of tension in the area of heterogeneity, which complies with the specified period of time $d t$. From expression (4) we find that the destruction speed, i.e. the number of destructed volumes in the unit of time, is determined by the expression

$$
\Phi(t)=\frac{d N_{p}}{d t}=N_{0} p[\sigma(t)]\left[\frac{d \sigma(t)}{d t}\right],
$$

As in the work [11], we will consider that destruction of every elementary volume is accompanied by forming a perturbation single-pulse, bell-like form. Per- 
turbation duration single-pulse $\delta$ being short and much less than the time of all the destruction process (crack development). We are not going to consider relaxation processes in perturbation pulse extension, i.e. we will consider that the perturbation pulse is not distorted and spreads without fading. There is no doubt that the perturbation pulse amplitude is determined by the value of local tension $\sigma$ applied, which is equal to critical tension that causes destruction. The more critical tension, the greater the amplitude of perturbation pulse is. We will therefore consider that proportion $A_{0}(t) \sim \sigma(t)$ is implemented, or

$$
A_{0}(t)=\zeta \sigma(t),
$$

where $A_{0}$ - amplitude of perturbation pulse indignation; $\zeta$ - proportion coefficient; $\sigma(t)$ - dependence of local tension change in time.

Then the perturbation pulse formed at destruction of one elementary volume will be written as a of product of its amplitude and the function of form

$$
A(t, \tau)=A_{0}(t) a(\tau),
$$

where $a(\tau)$ - function that determines the form of perturbation pulse; $\tau$ - time of perturbation pulse development, which is considerably less than the time of crack development.

It is thus assumed that the function $a(\tau)$ is identical for all destructed elementary volumes and has a single amplitude [11].

The resulting shift that is formed in the arbitrary moment of time is equal to the sum of perturbations from elementary volumes destroyed at a given moment of time. If perturbation duration single-pulse $\delta$ is much shorter than the time of crack formation, the expression for general formed shift at a given moment of time $t$, in accordance with, will be written down

$$
U_{T}(t)=A_{0}(t) \Phi(t) \delta_{s},
$$

where $U_{T}(t)$ - resulting shift; $\delta_{S}$ - integral parameter of the form of perturbation pulse, its numeral value being equal to $\delta_{S}=\int_{-\delta / 2}^{\delta / 2} a(\tau) d \tau[11]$.

Putting expressions (5), and (6) into (8) we will obtain the resulting displacement in the moment of time $t$, which is described by the correlation

$$
U_{T}(t)=\zeta \sigma(t) \delta_{S} N_{0} p[\sigma(t)] \frac{d \sigma(t)}{d t} .
$$

Let us assume that the external load applied to the model (Fig 1) changes under the linear law

$$
\sigma_{0}=\alpha t \text {, }
$$

where $\alpha$ - speed of loading, which is constant.

Because of random distribution of elementary volumes concerning strength, their destruction will have uneven character. Local tensions in area of heterogeneity $(\sigma(t))$ will therefore not be equal (10) but will change depending on the progress of elementary volume destruction process. With an increase in the amount of destructed elementary volumes, local tension in the area of heterogeneity, where destruction takes place, will increase. The speed of the growth of tension in the area of the heterogeneity depends not only on speed of inputting external tension, but also on the amount of the elementary volumes destructed. In other words, the more destructed volumes, the greater local tension $(\sigma(t)$, Fig 1) is applied to other volumes. For speed of local tension growth that results in destruction of elementary volumes in the area of heterogeneity it is therefore possible to write down the expression

$$
\alpha_{T}=\alpha\left(1+\kappa \int_{0}^{\sigma(t)} p(\sigma) d \sigma\right)
$$

where $\kappa$ - proportion coefficient.

With (10) and (11) taken into consideration the expression for temporal dependence of tension change in area of heterogeneity acquires rather complex appearance and is presented by the equation

$$
\sigma(t)=\alpha t\left(1+\kappa \int_{0}^{\sigma(t)} p(\sigma) d \sigma\right)
$$

Let us take the derivative from the equation (12) and we will obtain

$$
\frac{d \sigma(t)}{d t}=\alpha+\alpha \kappa \int_{0}^{\sigma(t)} p(\sigma) d \sigma+\alpha \kappa p(\sigma(t)) \frac{d \sigma(t)}{d t} .
$$

Solving equation (13) in relation to the derivative, we will get the expression for the tension derivative in the area of the heterogeneity

$$
\frac{d \sigma(t)}{d t}=\alpha \frac{1+\kappa \int_{0}^{\sigma(t)} p(\sigma) d \sigma}{1-\alpha \kappa p(\sigma)} .
$$

The expression (14) shows, that a denominator can not be equal to zero, i.e. inequality $1-\alpha \kappa p(\sigma)>0$ must be observed $(\sigma)>0$.

Putting into (12) the expression for distributing elementary volumes according to strength (3), we will see, that tension dependence on time is expressed by the integral

$$
\sigma(t)=\alpha\left\{1+c \kappa \int_{0}^{\sigma(t)} \sigma \exp (-b \sigma) d \sigma\right\} t .
$$

After calculating the integral in (15), this expression will be rewritten as follows

$$
\begin{aligned}
& \sigma(t)=\alpha t+\alpha \frac{c \kappa}{b} t\left\{\frac{1}{b}[1-\exp (-b \sigma(t))]-\right. \\
& -\sigma(t) \exp (-b \sigma(t))\} .
\end{aligned}
$$

Thus, it is seen from expression (15), that local tension change is found in solving the transcendent equation.

If correlations (9) - (13) are taken into account, the expression for resulting displacement will look like

$$
\begin{aligned}
U_{T}(t)= & \zeta \alpha t\left\{1+\kappa \int_{0}^{\sigma(t)} p(\sigma) d \sigma\right\} \delta_{s} N_{0} \times \\
& \times p[\sigma(t)] \alpha \frac{1+\kappa \int_{0}^{\sigma(t)} p(\sigma) d \sigma}{1-\alpha \kappa p(\sigma)} .
\end{aligned}
$$


Putting into (17) the distribution function (3), we will see that the expression for resulting shift now acquires the form

$$
\begin{aligned}
U_{T}(t)= & \zeta \alpha t\left[1+c \kappa \int_{0}^{\sigma(t)} \sigma \exp (-b \sigma) d \sigma\right] \delta_{s} N_{0} \alpha t(1+ \\
& \left.+c \kappa \int_{0}^{\sigma(t)} \sigma \exp (-b \sigma) d \sigma\right) \times \\
& \times \exp \left(-b \alpha t\left(1+c \kappa \int_{0}^{\sigma(t)} \sigma \exp (-b \sigma) d \sigma\right)\right) \alpha \times \\
& \times \frac{1+c \kappa \int_{0}^{\sigma(t)} \sigma \exp (-b \sigma) d \sigma}{1-\alpha c \kappa \sigma \exp (-b \sigma(t))}
\end{aligned}
$$

After calculating the integrals in (18) with reference to (16), we will get the following expression

$$
\begin{gathered}
U_{T}(t)=\zeta \alpha^{3} t^{2} \delta_{s} N_{0}\left\{1+c \frac{\kappa}{b}\left[\frac{1}{b}(1-\exp (-b \sigma(t))-\right.\right. \\
-\sigma(t) \exp (-b \sigma(t))]\}^{3} \exp (-b \alpha t\{1+ \\
\left.+c \frac{\kappa}{b}\left[\frac{1}{b}(1-\exp (-b \sigma(t))-\sigma(t) \exp (-b \sigma(t))]\right\}\right) / \\
/[1-\alpha c \kappa \sigma(t) \exp (-b \sigma(t))]
\end{gathered}
$$

It is quite obvious that investigation of (19) is rather complicated problem. Therefore we will consider some approximations.

The simplest is the case, when value $\kappa$ is small, i.e. $\kappa<<1$. Taking into account this approximation, the expression (20) is simplified and assumes the type

$$
\begin{aligned}
U_{T}(t)= & \zeta \alpha^{3} t^{2} \delta_{s} N_{0}\left\{1+c \frac{\kappa}{b}\left[\frac{1}{b}(1-\exp (-b \sigma(t))-\right.\right. \\
& -\sigma(t) \exp (-b \sigma(t))]\}^{3} \exp (-b \alpha t\{1+ \\
+c \frac{\kappa}{b} & {\left.\left[\frac{1}{b}(1-\exp (-b \sigma(t))-\sigma(t) \exp (-b \sigma(t))]\right\}\right) \times } \\
& \times[1+\alpha c \kappa \sigma(t) \exp (-b \sigma(t))]
\end{aligned}
$$

Moreover, when value $\kappa$ is small it is possible to find solution of equation (16) by presenting dependence of tension on time as a row on $\kappa$ :

$$
\sigma(t)=\alpha t+\kappa u_{1}+\kappa^{2} u_{2}+\ldots
$$

where the first sum is zero approximation, $\sigma_{0}(t)=\alpha t$, a $u_{1}(t), u_{2}(t)$ - unknown functions. If we limit ourselves only to the first infinitesimal order, we will find dependence $u_{1(\mathrm{t})}$, which we will write down as

$$
u_{1}(t)=\alpha \frac{c}{b} t\left\{\frac{1}{b}[1-\exp (-b \alpha t)]-\alpha t \exp (-b \alpha t)\right\} \text {. }
$$

Now expression for tension in the area of heterogeneity will look like

$\sigma(t)=\alpha t+\alpha \kappa \frac{c}{b} t\left\{\frac{1}{b}[1-\exp (-b \alpha t)]-\alpha t \exp (-b \alpha t)\right\}$

In Fig 2, dependencies of local tension change are presented in the area of the heterogeneity, in obedience to expression (23), in relative units. Dependencies were built for conditions when $k$ is equal to zero $(k=0)$, i.e. self-acceleration of destruction process is absent (change of local tension is equal to external tension change), and when $k=0,4$, i.e. there is self-acceleration of the destruction process. In drawing graphs, the values $\alpha=40, b=15$ were accepted. Value $c$ in distribution (3) was determined from the normalization condition, i.e. $c=b^{2}$.
It is apparent from the results obtained that destruction process self-acceleration results in non-linearity in the dependence of changing local tension in time, local tension in relation to external tension being increased.

We will find the derivative from expression (23)

$$
\begin{aligned}
\frac{d \sigma(t)}{d t}= & \alpha\left(1+\kappa \frac{c}{b}\left\{\frac{1}{b}[1-\exp (-b \alpha t)]-\right.\right. \\
& -\alpha t \exp (-b \alpha t)\})+\alpha^{3} \kappa c t^{2} \exp (-b \alpha t) .
\end{aligned}
$$

We will put (23) into (20) and obviously obtain the dependence of resulting shift on time, which acquires the form

$$
\begin{aligned}
U_{T}(t)= & \alpha^{3} t^{2} \delta_{s} U_{0}\left\{1+c \frac{\kappa}{b}\left[\frac{1}{b}(1-\exp (-b \alpha t)-\right.\right. \\
& -\alpha t \exp (-b \alpha t)]\}^{3} \exp \left(-b \alpha t\left\{1+c \frac{\kappa}{b}\left[\frac{1}{b}(1-\right.\right.\right. \\
& -\exp (-b \alpha t)-\alpha t \exp (-b \alpha t)]\}) \times \\
& \times\left[1+\alpha^{2} c \kappa t \exp (-b \alpha t)\right],
\end{aligned}
$$

where designation $U_{0}=\zeta N_{0}$, which is the peak value of the shift resulting pulse, is entered (AE signal). We are talking about AE signal, because in case of a broad-band transducer the output electric signal repeat the pulse of mechanical shift $U_{T}(t)$.

We will write down expression (25) in a different way

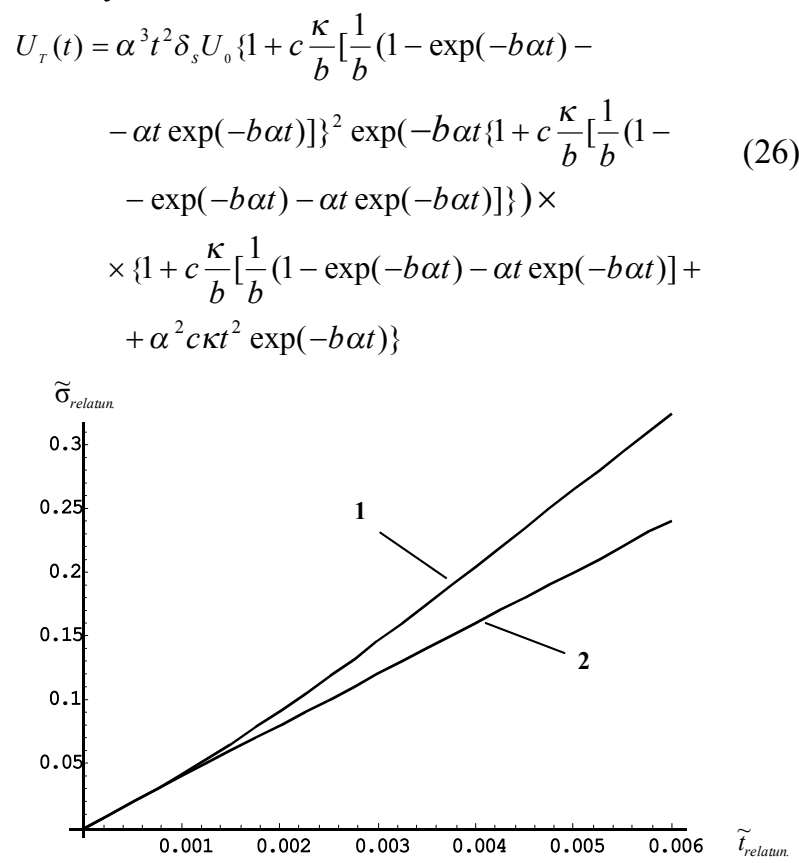

Fig 2. Dependencies of tension change (in relative units) in local area of heterogeneity with constant speed of specimen loading: $1-\kappa=0,4 ; 2-\kappa=0$. For both graphs $\alpha=40, b=15$

In case of independent destruction of elementary volumes in the area of heterogeneity, i.e. if selfacceleration of destruction process is absent, parameter value $k$ will equal zero, $\kappa=0$. If this parameter value $k$ is put into (25), we will receive the expression

$$
U_{T}(t)=U_{0} \delta_{S} \alpha^{3} t^{2} \exp (-b \alpha t) .
$$


Expression (27) corresponds to the model of the AE signal when a fragile crack is formed in the material [16], on the condition that dependence of tension change in the

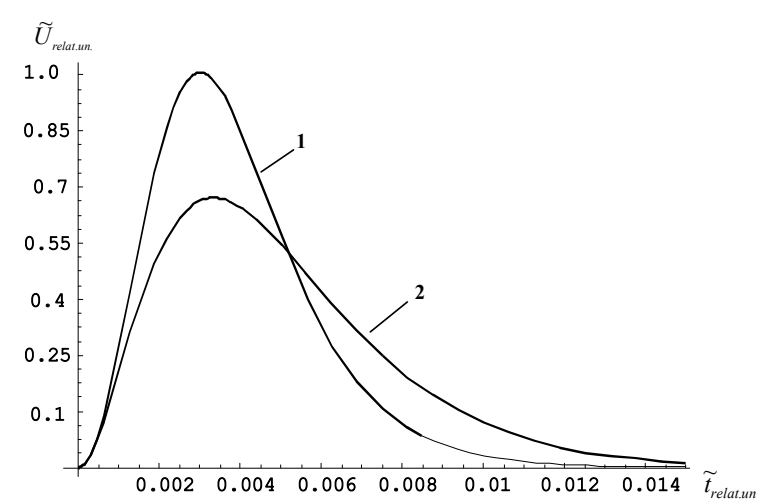

Fig 3. Dependencies of change of resulting shift in relative units: 1 - calculations according to expression (26), if $\kappa=0,4 ; 2$ - calculations according to expression (27), if $\kappa=0$. For both graphs $\alpha=40, b=15$ is accepted. $\tilde{U}_{\text {relat.un. }}$ - rationed value on

$U_{\max } \cdot \tilde{t}_{\text {relat.un. }}$ - rationed value on $t_{\max }=$ const

area of the heterogeneity (local tension) corresponds to the dependence of change in the external tension applied.

The calculation results in change dependencies $\tilde{U}(t)=U_{T}(t) / U_{o}$ in relative units, according to expressions (26) and (27), are shown in Fig 3. When drawing graphs (Fig 3) time rationed for time of loading which has constant value $\left(t_{\max }\right)$. Parameters $\alpha$ and $b$ are reduced to dimensionless values. For curve 1, Fig 3 the value of $k$ was accepted equal $k=0,4$.

It can be seen in Fig 3 that self-acceleration of thedestruction process of elementary volumes in the area of the heterogeneity results in growth of local tensions, and leads to compression of AE signal and increase of its amplitude. It is well coordinated with the results of AE signal modeling from crack, when the conditions of uneven growth of speed in the final stages of its development have been modeled [9].

\section{Conclusions}

The results of the research carried out show, that self-acceleration of the process of destruction development leads to compression of AE signal. It should be noted that this compression in the growth of selfacceleration degree is accompanied by symmetrization of the shape of the signal formed and the degree of selfacceleration of the destruction process gradually increases. As calculations show, the transformation of the AE signal into a of triangular form signal which is also observed in the results of experimental research], takes place $[12,9]$. According to the results obtained, it is influenced by the acceleration of the process of destruction at the final stage of its development, when, as is seen in Fig 2, deviation of temporal dependence of tension change in the local area of heterogeneity from linear motion takes place.

\section{References}

1. Gorman M.R., Prosser W.H. Application of Normal Mode Expansion to AE Waves in Finite Plates // Journal of Applied Mechanics. - 1996. - Vol 63. - P. 555-557.

2. Houle P.A., Sethna J.P. Acoustic emission from crumpling paper // Physical review E. 1996. - Vol 54, No 1. -P. 278-283.

3. Lei X., Kusunose K. Quasi-static fault growth and cracking in homogeneous brittle rock under triaxial compressing using acoustic emission monitoring // J. of Geophis. Research. - 2000. Vol 105, No B3. -P. 6127-6139.

4. Lei X, Masuda K, Nishizawa O. et al. Detailed analysis of acoustic emission activity during catastrophic fracture of faults in rock // J. Of Structural Geology. - 2004. - No 26. - P. 247258.

5. Lypez Pumarega M.I., Piotrkowski R., Ruzzante J.E. Discussion of log-normal distribution of amplitude in acoustic emission signals // J. Of acoustic emission. - 1999. - Vol 17, No 1-2. - P. 61-67.

6. Olih Y.M. Acoustic emission in halcogenic glass $\mathrm{Gl}_{0.18} \mathrm{As}_{0.28} \mathrm{Sl}_{0.5} / /$ FTT. - 1998. - Vol 40, No 9. - P.1623-1626.

7. Serdobolskaja O.Yu. Acoustical emission at destruction of KCl TGS crystals // XIII Session of the Russian Acoustical Society, Moscow, August 25-29, 2003. - 2003. - P.111-113.

8. Андрейкив А.Е., Лысак Н.В. Метод акустической эмиссии в исследовании процессов разрушения. -К: Наукова думка, 1989. $-176 \mathrm{c}$.

9. Бабак В.П., Філоненко С.Ф., Калита В.М. Моделювання сигналів акустичної емісії при виникненні в матеріалі тріщин //Вісник НАУ. - 2002. -№ 1. - С. 5-10.

10. Бабак В.П., Филоненко С.Ф., Калита В.М. Моделирование сигналов акустической эмиссии при протекании в материале пластической деформации // Технологические системы. - 2002. -№3(14). - C. 77-81.

11. Бабак В.П., Филоненко С.Ф., Калита В.М. Модели формирования сигналов акустической эмиссии при деформировании и разрушении материалов // Технологические системы. - 2002. - №1(12). - C. 26-34.

12. Бабак В.П., Филоненко С.Ф., Калита В.М. Модель сигнала акустической эмиссии при образовании в материале трещины с учетом релаксационных процессов // Технологические системы. - 2002. -№ 5(16). - С. 20-23.

13. Бернштейн М.Л., Займовский В.А. Структура и механические свойства 
металлов. - М: Издательство Металлургия, 1970. $-472 \mathrm{c}$.

14. Вайнберг В.Е., Кантор А.Ш., Лупашку Р.Г. Применение кинетической концепции разрушения для расчета интенсивности акустической эмиссии // Дефектоскопия. 1976. - № 3. - С. 89-96.

15. Грешников В.А., Дробот Ю.В. Акустическая эмиссия. Применение для испытаний материалов и изделий. - М: Издво стандартов, 1976. - 272 с.

16. Иванов В.И. Акустическая эмиссия в процессе когерентного разрушения // Доклады АН СССР. - 1986. - Т. 287, № 2. С. 302-306.

17. Иванов В.И., Белов В.М. Акустоэмиссионный контроль сварки и сварных соединений. - М: Машиностроение, 1981. $184 \mathrm{c}$.
18. Маламедов И.М. Физические основы надежности. - Л.:Энергия, 1970. - 152 с.

19. Регель В.Р., Слуцкер А.И., Томашевский Э.Е. Кинетическая природа прочности твердых тел. -М.: Наука, 1974. - 560 с.

20. Филоненко С.Ф. Акустическая эмиссия. Измерение, контроль, диагностика. - К.: Издат-во КМУГА, 1999. - 304 с.

21. Филоненко С.Ф., Городыский Н.И., Бирюков В.С. Особенности сигналов акустической эмиссии при пластическом деформировании и хрупком разрушении материалов // Физ.-хим. механика материалов. -1985. - № 6. - С. 105-106.

22. Финкель В.М. Физика разрушения. - М.: Металлургия, 1970. - 376 с. 